\title{
FAKTOR-FAKTOR YANG BERHUBUNGAN DENGAN \\ PEMBERIAN MP-ASI DINI DI DESA BOLOH KECAMATAN TOROH KABUPATEN GROBOGAN
}

\author{
Priharyanti Wulandari $^{(1)}$, Dwi Nur Aini (2), Desi Mega Kurnia Sari ${ }^{(3)}$ \\ Program Studi Ilmu Keperawatan STIKES Widya Husada Semarang \\ Jl. Subali Raya No.12 Krapyak Semarang, Tlp 024-7612988-7612944 \\ Email:wulancerank@yahoo.co.id
}

\begin{abstract}
ABSTRAK
Berdasarkan studi pendahuluan dengan wawancara pada 4 ibu yang mempunyai bayi usia 0-6 bulan, ibu mengatakan mulai memberikan MP-ASI pada bayinya sejak umur 1 bulan. Tujuan penelitian untuk mengetahui hubungan antara usia ibu, status pekerjaan, tingkat pendidikan, pengetahuan, pengalaman, sosial budaya, dan informasi dengan pemberian MP-ASI Dini di Desa Boloh Kecamatan Toroh Kabupaten Grobogan. Jenis penelitian ini adalah desain deskriptif korelatif dengan rancangan cross sectional. Populasi sebanyak 81 ibu yang memiliki bayi usia $<6$ bulan. Sampel dalam penelitian ini adalah 78 ibu dengan teknik Accidental Sampling dan analisisnya menggunakan chi square dengan $\alpha=0,05 \%$. Hasil penelitian ini menunjukkan ada tujuh variabel yang berhubungan dengan pemberian MP-ASI Dini yaitu usia ibu nilai $\mathrm{p}_{\text {value }} \leq 0,05(\mathrm{p}=0,028)$, status pekerjaan nilai $\mathrm{p}_{\text {value }}$ $\leq 0,05(p=0,002)$, tingkat pendidikan Dini nilai $p_{\text {value }} \leq 0,05(p=0,001)$, pengetahuan nilai $p_{\text {value }} \leq 0,05(p=0,020)$, pengalaman nilai $p_{\text {value }} \leq 0,05(p=0,005)$, sosial budaya $\mathrm{p}_{\text {value }} \leq 0,05(\mathrm{p}=0,001)$, informasi nilai $\mathrm{p}_{\text {value }} \leq 0,05(\mathrm{p}=0,001)$. Ada hubungan yang signifikan antara umur ibu, status pekerjaan,tingkat pendidikan, pengetahuan, pengalaman, sosial budaya, dan informasi.
\end{abstract}

Kata Kunci : Usia Ibu, status pekerjaan, tingkat pendidikan, pengetahuan, pengalaman, sosial budaya, informasi dan pemberian MP-ASI Dini.

Daftar Pustaka : 36 ( 2007-2014).

\begin{abstract}
FACTORS RELATED TO GIVING EARLY COMPLEMENTARY FEEDING IN THE VILLAGE BOLOH TOROH DISTRICT DISTRICT GROBOGAN

Based on the preliminary study by interviews with four mothers of infants aged 0-6 months, the mother said start giving breast milk to their infants from the age of 1 month. The aim of research to determine the relationship between maternal age, employment status, level of education, knowledge, experience, social, cultural, and information with the provision of Early Complementary Feedinng in the Village Boloh Toroh Subdistrict Grobogan. This research is a descriptive correlative design with cross sectional design. A population of about 81 mothers with babies younger than 6 months The sample in this study was 78 mothers with accidental
\end{abstract}


sampling techniques and analysis using chi square with $\alpha=0.05 \%$. The results of this study indicate there are seven variables related to the provision of early complementary feeding maternal age pvalue $\leq 0.05(p=0.028)$, employment status pvalue $\leq 0.05(p=0.002)$, education level Dini pvalue $\leq 0.05(p=0.001)$, knowledge pvalue $\leq 0.05(p=0.020)$, experience pvalue $\leq 0.05(p=0.005)$, social and cultural pvalue $\leq 0.05(p=0.001)$, information pvalue $\leq 0.05(p=0.001)$. There was a significant correlation between maternal age, employment status, level of education, knowledge, experience, social cultural, and information.

Keywords: Maternal age, employment status, level of education, knowledge, experience, social cultural, information and provision of early complementary feeding.

Biliography: 36 ( 2007-2014).

\section{PENDAHULUAN}

Air susu ibu ( ASI ) mengandung zat gizi yang diperlukan bayi dalam enam bulan pertama setelah dilahirkan. Tanpa diberi cairan tambahan lain selain ASI, karena dapat meningkatkan kemungkinan terkontaminasi dan meningkatkan risiko terkena penyakit, khususnya diare. Setelah berusia enam bulan maka ASI harus ditambah dengan cairan lain dan makanan padat untuk memberikan gizi yang dapat memadai. ASI dan MP-ASI diberikan sampai anak berusia dua tahun ( BKKBN dan Kemenkes RI, 2012). MPASI ( Makanan Pendamping Air Susu Ibu ) adalah makanan yang mengandung sumber gizi yang diberikan saat bayi berusia setelah enam bulan keatas. ( Ellya, 2010 ).

Penelitian WHO ( 2011 ), menyatakan bahwa hanya $40 \%$ bayi di dunia yang mendapatkan ASI eksklusif sedangkan $60 \%$ bayi lainnya ternyata telah mendapatkan MP-ASI saat usianya $<$ dari 6 bulan. Penelitian yang dilakukan Jane et.al di Perth, Australia, menunjukkan bahwa $44 \%$ bayi telah diberikan makanan padat sebelum berusia 17 minggu. Beberapa penelitian lain menunjukan bahwa bayi sudah diberikan makanan padat sebelum usia 4 bulan yaitu $45 \%$ di Selandia Baru, $63 \%$ di Finlandia, dan $70 \%$ di Kanada. Bahkan dari hasil penelitian di Skotlandia menunjukan bahwa $40 \%$ bayi telah diberikan makanan padat pada usia 12 minggu.

Menurut Riset Kesehatan Dasar ( 2013 ), bayi yang mendapatkan ASI eksklusif berjumlah $30,2 \%$ sedangkan bayi yang telah diberikan MP-ASI adalah $69,8 \%$ dari seluruh total bayi di Indonesia.

Berdasarkan data yang diperoleh dari profil kesehatan di Provinsi Jawa Tengah tahun 2009 jumlah bayi ( 0 - 6 bulan ) di Semarang 8.453, namun yang diberi ASI eksklusif hanya 1.175 ( $13,80 \%$ ).

Dalam pemberian MP-ASI dini dipengaruhi dua faktor, yaitu faktor internal dan faktor eksternal. Faktor internal meliputi pengetahuan, pengalaman dan tingkat pendidikan, dan faktor eksternal meliputi sosial budaya, dan informasi. Apabila orang tua memiliki pengetahuan yang baik tentang pentingnya pemberian ASI, maka akan memberikan ASI saja sampai bayi berusia enam bulan, apabila pengetahuan ibu rendah maka akan memberikan MPASI sebelum usia enam bulan, dan beranggapan agar bayinya merasa kenyang ( Notoadmodjo, 2005 ).

Pengalaman Ibu yang sudah pernah mempunyai anak cenderung lebih berpengalaman dalam memberi MP-ASI dini pada anaknya, dan tidak terjadi masalah sehingga ibu akan membawa 
pengalaman tersebut pada anak selanjutnya. Pendidikan ibu lebih tinggi akan lebih cepat menerima dan memahami informasi dibanding dengan yang berpendidikan rendah (Solichaturrohmah, 2012 ).

Menurut Notoadmodjo ( 2005 ) Kepercayaan, adat istiadat, dan tradisi yang ada yang membawa perilaku ibu dalam pemberian MP-ASI dini dimana kebiasaan masyarakat setempat yang memberikan bayinya bubur susu ataupun pisang kerok. Selain itu karena menurut ibu bayi yang menangis menunjukkan bayi masih lapar sehingga harus diberi makanan tambahan. Banyaknya iklan dan produk yang ditawarkan mengenai makanan sereal bayi dan susu formula, sehingga memudahkan ibu untuk memperoleh informasi.

Berdasarkan data awal yang diperoleh dari Posyandu Desa Boloh Kecamatan Toroh Kabupaten Grobogan pada tanggal 06 April 2016, terdapat 81 bayi berusia 0-6 bulan. Dan hasil wawancara pada 4 ibu yang mempunyai bayi usia 0-6 bulan, ibu mengatakan mulai memberikan makanan pada bayinya seperti pisang dikerok, bubur beras, dan makanan yang dikunyah oleh ibu, sejak umur1bulan. Karena ibu merasa bayi akan kekurangan gizi jika hanya diberikan ASI. Dan sebagian ibu juga mengatakan bahwa setelah diberikan MP-ASI kurang dari usia 6 bulan bayinya sering mengalami diare, sembelit, dan muntah.

Berdasarkan latar belakang penelitian diatas, maka rumusan masalah dalam penelitian ini adalah " Adakah faktor faktor yang berhubungan dengan pemberian MP-ASI dini di Desa Boloh Kecamatan Toroh Kabupaten Grobogan”?.

\section{METODE PENELITIAN}

Desain: Jenis penelitian yang digunakan dalam penelitian ini adalah studi deskriptif korelasi yang bertujuan untuk menguji hipotesis mengenai kemungkinan hubungan antar variabel (Notoadmodjo, 2010). Metode pengumpulan data dengan pendekatan cross sectional yaitu suatu penelitian untuk mempelajari dinamika korelasi antara faktor-faktor resiko dengan efek, dengan cara pendekatan, observasi atau pengumpulan data sekaligus pada suatu saat ( point time approach).

Populasi: Dalam penelitian ini adalah semua ibu yang mempunyai bayi berusia 0 6 bulan di Desa Boloh Kecamatan Toroh Kabupaten Grobogan yaitu sebanyak 81ibu.

Sampel: Dalam penelitian ini sebanyak $78 \mathrm{ibu}$ yang bersedia menjadi responden sesuai kriteria inklusi dan eksklusi yang ada di Desa Boloh Kecamatan Toroh Kabupaten Grobogan.

Diambil secara Accidental sampling yaitu peneliti mengumpulkan data dari subjek yang ditemuinya, saat itu dalam jumlah secukupnya. Cara ini cocok untuk mengetahui opini masyarakat terhadap topic tertentu (Saryono, 2013).

Instrument: Alat pengumpulan data yang digunakan berupa lembar kuesioner. Kuesioner atau pernyataan tersebut terdiri dari beberapa bagian. Bagian pertama berisi data demografi (nama, umur, pendidikan, dan status pekerjaan).

Bagian kedua berisi 15 pertanyaan tentang faktor pengetahuan, 13 pertanyaan tentang faktor pengalaman, 8 pertanyaan tentang faktor sosial budaya, dan 7 pertnyaan tentang faktor informasi yang berhubungan dengan pemberian MP-ASI dini di Desa Boloh Kecamatan Toroh Kabupaten Grobogan.

Analisa Data: menggunakan analisa Univariat dan Analisa Bivariat dan analisisnya menggunakan chi square dengan $\alpha=0,05 \%$.

\section{HASIL PENELITIAN}

Berdasarkan penelitian didapatkan hasil sebagai berikut :

\section{Karakteristik responden berdasarkan usia ibu}




\section{Tabel 3}

\section{Tabel 1}

Distribusi Frekuensi Responden Berdasarkan Usia Ibu Di Desa Boloh Kecamatan Toroh

Kabupaten Grobogan

Bulan Juni 2016 (n=78)

\begin{tabular}{ccc}
\hline Usia Ibu & $\begin{array}{c}\text { Frekuensi } \\
(\mathrm{n})\end{array}$ & Presentase (\%) \\
\hline Usia & 29 & 37,2 \\
$\begin{array}{c}\text { Remaja } \\
(<20 \text { th) }\end{array}$ & 29 & \\
\hline Usia & & \\
Dewasa & 36 & 46,2 \\
Awal (20- & & \\
35th) & & \\
\hline Usia & & \\
Dewasa & 13 & 16,7 \\
Akhir & & \\
$(>35$ th) & & \\
\hline
\end{tabular}

Berdasarkan hasil tabel menunjukkan bahwa sebagian besar responden berusia dewasa awal ( 20-35 tahun ) dengan jumlah 36 ibu $(46,2 \%)$.

\section{Karakteristik responden berdasarkan pekerjaan}

\section{Tabel 2}

Distribusi Frekuensi Responden Berdasarkan status pekerjaan Ibu

Di Desa Boloh Kecamatan Toroh Kabupaten

Grobogan

Bulan Juni $2016(n=78)$

\begin{tabular}{ccc}
\hline $\begin{array}{c}\text { Status } \\
\text { Pekerjaan }\end{array}$ & Frekuensi (n) & $\begin{array}{c}\text { Presentase } \\
(\%)\end{array}$ \\
\hline $\begin{array}{c}\text { Tidak } \\
\text { Bekerja }\end{array}$ & 32 & 41,0 \\
\hline Bekerja & 46 & 59,0 \\
\hline
\end{tabular}

Berdasarkan hasil tabel menunjukkan bahwa sebagian besar responden bekerja dengan jumlah 46 ibu $(59,0 \%)$.

\section{Karakteristik responden berdasarkan status pekerjaan}

Distribusi Frekuensi Responden Berdasarkan Tingkat Pendidikan Ibu

Di Desa Boloh Kecamatan Toroh

Kabupaten Grobogan

Bulan Juni 2016 ( $n=78)$

\begin{tabular}{ccc}
\hline $\begin{array}{c}\text { Pendidikan } \\
\text { Ibu }\end{array}$ & $\begin{array}{c}\text { Frekuensi } \\
(\mathrm{n})\end{array}$ & Presentase (\%) \\
\hline $\begin{array}{c}\text { SD dan } \\
\text { SMP }\end{array}$ & 37 & 47,4 \\
\hline $\begin{array}{c}\text { SMA dan } \\
\text { Perguruan } \\
\text { Tinggi }\end{array}$ & 41 & 52,6 \\
\hline
\end{tabular}

Berdasarkan hasil tabel menunjukkan bahwa sebagian besar responden memiliki pendidikan SMA dan Perguruan Tinggi dengan jumlah $41 \mathrm{ibu}(52,6 \%)$.

\section{Faktor pengetahuan ibu}

Tabel 4

Distribusi Frekuensi Responden Berdasarkan Pengetahuan Ibu

Di Desa Boloh Kecamatan Toroh

Kabupaten Grobogan

Bulan Juni $2016 \quad(n=78)$

\begin{tabular}{ccc}
\hline $\begin{array}{c}\text { Pengetahua } \\
\mathrm{n}\end{array}$ & $\begin{array}{c}\text { Frekuensi } \\
(\mathrm{n})\end{array}$ & $\begin{array}{c}\text { Presentas } \\
\mathrm{e}(\%)\end{array}$ \\
\hline Kurang & 19 & 24,4 \\
\hline Cukup & 25 & 32,1 \\
\hline Baik & 34 & 43,6 \\
\hline
\end{tabular}

Berdasarkan hasil tabel menunjukkan bahwa sebagian besar responden memiliki pengetahuan baik dengan jumlah $34 \mathrm{ibu}$ ( 43,6\%).

\section{Faktor pengalaman ibu}

\section{Tabel 5}

Distribusi Frekuensi Responden Berdasarkan Pengalaman ibu

Di Desa Boloh Kecamatan Toroh

Kabupaten Grobogan

Bulan Juni 2016 (n=78) 


\begin{tabular}{ccc}
\hline Pengalaman & $\begin{array}{c}\text { Frekuensi } \\
(\mathrm{n})\end{array}$ & $\begin{array}{c}\text { Presentase } \\
(\%)\end{array}$ \\
\hline Kurang & 17 & 21,8 \\
\hline Cukup & 26 & 33,3 \\
\hline Baik & 35 & 44,9 \\
\hline
\end{tabular}

Berdasarkan hasil tabel menunjukkan bahwa sebagian besar responden memiliki pengalaman baik dengan jumlah $35 \mathrm{ibu}$ (44,9\%).

\section{Faktor Sosial Budaya}

Tabel 6

Distribusi Frekuensi Responden Berdasarkan Sosial Budaya Di Desa Boloh Kecamatan Toroh Kabupaten Grobogan Bulan Juni 2016 $(\mathrm{n}=78)$

\begin{tabular}{ccc}
\hline $\begin{array}{c}\text { Sosial } \\
\text { Budaya }\end{array}$ & $\begin{array}{c}\text { Frekuensi } \\
(\mathrm{n})\end{array}$ & $\begin{array}{c}\text { Presentase } \\
(\%)\end{array}$ \\
\hline Terpengaruh & 35 & 44,9 \\
\hline $\begin{array}{c}\text { Tidak } \\
\text { Terpengaruh }\end{array}$ & 43 & 55,1 \\
\hline
\end{tabular}

Berdasarkan hasil tabel menunjukkan bahwa sebagian besar responden tidak terpengaruh sosial budaya dengan jumlah 43 ibu $(55,1 \%)$.

\section{Faktor Informasi}

\section{Tabel 7}

Distribusi Frekuensi Responden Berdasarkan Informasi Ibu
Di Desa Boloh Kecamatan Toroh Kabupaten Grobogan Bulan Juni 2016 (n=78)

\begin{tabular}{ccc}
\hline Informasi & $\begin{array}{c}\text { Frekuensi } \\
(\mathrm{n})\end{array}$ & $\begin{array}{c}\text { Presentase } \\
(\%)\end{array}$ \\
\hline $\begin{array}{c}\text { Tidak } \\
\text { Terpengaruh }\end{array}$ & 42 & 53,8 \\
\hline Terpengaruh & 36 & 46,2 \\
\hline
\end{tabular}

Berdasarkan hasil tabel menunjukkan bahwa sebagian besar responden tidak terpengaruh informasi dengan jumlah 42 ibu $(53,8 \%)$.

\section{Pemberian MP-ASI Dini}

\section{Tabel 8}

Distribusi Frekuensi Responden Berdasarkan Pemberian MP-ASI Dini

Di Desa Boloh Kecamatan Toroh Kabupaten Grobogan Bulan Juni $2016(n=78)$

\begin{tabular}{ccc}
\hline $\begin{array}{c}\text { Pemberian } \\
\text { MP-ASI Dini }\end{array}$ & $\begin{array}{c}\text { Frekuensi } \\
(\mathrm{n})\end{array}$ & $\begin{array}{c}\text { Presentase } \\
(\%)\end{array}$ \\
\hline Memberiakan & 47 & 60,3 \\
\hline $\begin{array}{c}\text { Tidak } \\
\text { Memberikan }\end{array}$ & 31 & 39,7 \\
\hline
\end{tabular}

Berdasarkan hasil tabel menunjukkan bahwa sebagian besar responden memberikan MP-ASI Dini dengan jumlah $47 \mathrm{ibu}(60,3 \%)$. 


\section{Hubungan Usia Ibu dengan Pemberian MP-ASI Dini}

\section{Tabel 9}

Hubungan Usia Ibu dengan Pemberian MP-ASI Dini di Desa Boloh KecamatanToroh Kabupaten Grobogan

Bulan Juni $2016(\mathrm{n}=78)$

\begin{tabular}{|c|c|c|c|c|c|c|c|c|}
\hline \multirow{3}{*}{ Usia Ibu } & \multicolumn{4}{|c|}{ Pemberian MP-ASI Dini } & \multirow{2}{*}{\multicolumn{2}{|c|}{ Total }} & \multirow{3}{*}{$\mathbf{x}^{2}$} & \multirow{3}{*}{$\begin{array}{l}\mathbf{P} \\
\text { value }\end{array}$} \\
\hline & \multicolumn{2}{|l|}{$\mathrm{Ya}$} & \multicolumn{2}{|c|}{ Tidak } & & & & \\
\hline & $\mathrm{n}$ & $\%$ & $\mathrm{n}$ & $\%$ & $\mathrm{n}$ & $\%$ & & \\
\hline $\begin{array}{l}\text { Remaja } \\
(<20 \text { Th })\end{array}$ & 22 & 28,2 & 7 & 9,0 & 29 & 37,2 & 7,145 & 0,028 \\
\hline $\begin{array}{l}\text { Dewasa Awal } \\
(20-35 \text { Th) }\end{array}$ & 16 & 20,5 & 20 & 25,6 & 36 & 46,2 & & \\
\hline $\begin{array}{l}\text { Dewasa Akhir } \\
\text { ( >35 Th ) }\end{array}$ & 9 & 11,5 & 4 & 5,1 & 13 & 16,7 & & \\
\hline Jumlah & 47 & 60,3 & 31 & 39,7 & 78 & 100 & & \\
\hline
\end{tabular}

Berdasarkan hasil uji statistik dengan menggunakan uji Chi-square diperoleh nilai $\mathrm{x}^{2}=7,145$ dan nilai $p=0,028<\alpha=$ 0,05 , maka Ho ditolak dan Ha diterima artinya terdapat hubungan yang bermakna antara usia ibu dengan pemberian MP-ASI Dini di Desa Boloh Kecamatan Toroh Kabupaten Grobogan.

\section{Hubungan Status Pekerjaan dengan Pemberian MP-ASI Dini}

\section{Tabel 10}

Hubungan Pekerjaan dengan Pemberian MP-ASI Dini

di Desa Boloh Kecamatan Toroh Kabupaten

Grobogan Bulan Juni $2016(n=78)$

\begin{tabular}{|c|c|c|c|c|c|c|c|c|}
\hline \multirow{3}{*}{$\begin{array}{l}\text { Status } \\
\text { Pekerjaan }\end{array}$} & \multicolumn{4}{|c|}{$\begin{array}{l}\text { Pemberian } \\
\text { MP-ASI Dini }\end{array}$} & \multirow{2}{*}{\multicolumn{2}{|c|}{ Total }} & \multirow{3}{*}{$\mathbf{x}^{2}$} & \multirow{3}{*}{$\underset{\text { value }}{\mathbf{p}}$} \\
\hline & \multicolumn{2}{|c|}{$\mathrm{Ya}$} & \multicolumn{2}{|c|}{ Tidak } & & & & \\
\hline & $\mathrm{n}$ & $\%$ & $\mathrm{n}$ & $\%$ & $\mathrm{n}$ & $\%$ & & \\
\hline $\begin{array}{l}\text { Tidak } \\
\text { Bekerja }\end{array}$ & 26 & 33,3 & 6 & 7,7 & 32 & 41,0 & 9,986 & 0,002 \\
\hline Bekerja & 21 & 26,9 & 25 & 32,1 & 46 & 59,0 & & \\
\hline Jumlah & 47 & 60,3 & 31 & 39,7 & 78 & 100 & & \\
\hline
\end{tabular}

Berdasarkan hasil uji statistik dengan menggunakan uji Chi-square untuk mengetahui hubungan antara pekerjaan dengan pemberian MP-ASI Dini, diperoleh nilai $x^{2}=9,986$ dan nilai $p=0,002<\alpha=0,05$, maka Ha diterima dan Ho ditolak artinya terdapat hubungan yang bermakna antara status pekerjaan ibu dengan pemberian MP-ASI Dini di Desa Boloh Kecamatan Toroh Kabupaten Grobogan. 


\section{Hubungan Pendidikan Ibu dengan Pemberian MP-ASI Dini}

\section{Tabel 11}

Hubungan Pendidikan dengan Pemberian MP-ASI Dini

Di Desa Boloh KecamatanToroh Kabupaten Grobogan Bulan Juni $2016(\mathrm{n}=78)$

\begin{tabular}{|c|c|c|c|c|c|c|c|c|}
\hline \multirow[t]{3}{*}{ Pendidikan } & \multicolumn{4}{|c|}{ Pemberian MP-ASI Dini } & \multirow{2}{*}{\multicolumn{2}{|c|}{ Total }} & \multirow[t]{3}{*}{$\mathbf{x}^{2}$} & \multirow{3}{*}{$\begin{array}{l}P \\
\text { value }\end{array}$} \\
\hline & \multicolumn{2}{|l|}{$\mathrm{Ya}$} & \multicolumn{2}{|c|}{ Tidak } & & & & \\
\hline & $\mathrm{n}$ & $\%$ & $\mathrm{n}$ & $\%$ & $\mathrm{n}$ & $\%$ & & \\
\hline SD dan SMP & 26 & 33,3 & 6 & 7,7 & 32 & 41,0 & 9,986 & 0,002 \\
\hline $\begin{array}{l}\text { SMA dan } \\
\text { Perguruan } \\
\text { Tinggi }\end{array}$ & 21 & 26,9 & 25 & 32,1 & 46 & 59,0 & & \\
\hline Jumlah & 47 & 60,3 & 31 & 39,7 & 78 & 100 & & \\
\hline
\end{tabular}

Berdasarkan hasil uji statistik dengan menggunakan uji Chi-square untuk mengetahui hubungan antara tingkat pendidikan dengan pemberian MP-ASI Dini, diperoleh nilai $x^{2}=10,089$ dan nilai $p=$ $0,001<\alpha=0,05$, maka Ha diterima dan Ho ditolak artinya terdapat hubungan yang bermakna antara pendidikan ibu dengan pemberian MP-ASI Dini di Desa Boloh Kecamatan Toroh Kabupaten Grobogan.

\section{Hubungan Pengetahuan Ibu dengan Pemberian MP-ASI Dini}

Tabel 12

Hubungan Pengetahuan dengan Pemberian MP-ASI Dini

Di Desa Boloh KecamatanToroh Kabupaten Grobogan Bulan Juni $2016(n=78)$

\begin{tabular}{|c|c|c|c|c|c|c|c|c|}
\hline \multirow[t]{3}{*}{ Pengetahuan } & \multicolumn{4}{|c|}{$\begin{array}{c}\text { Pemberian } \\
\text { MP-ASI Dini }\end{array}$} & \multirow{2}{*}{\multicolumn{2}{|c|}{ Total }} & \multirow[t]{3}{*}{$\mathrm{x}^{2}$} & \multirow[t]{3}{*}{$\begin{array}{l}\mathbf{p} \\
\text { value }\end{array}$} \\
\hline & \multicolumn{2}{|c|}{$\mathrm{Ya}$} & \multicolumn{2}{|c|}{ Tidak } & & & & \\
\hline & $\mathrm{n}$ & $\%$ & $\mathrm{n}$ & $\%$ & $\mathrm{n}$ & $\%$ & & \\
\hline Kurang & 12 & 15,4 & 7 & 9,0 & 19 & 24,4 & 7,834 & 0,020 \\
\hline Cukup & 20 & 25,6 & 5 & 6,4 & 25 & 32,1 & & \\
\hline Baik & 15 & 19,2 & 19 & 24,4 & 34 & 43,6 & & \\
\hline Jumlah & 47 & 60,3 & 31 & 39,7 & 78 & 100 & & \\
\hline
\end{tabular}

Hasil uji Chi-square untuk mengetahui hubungan antara pengetahuan ibu dengan pemberian MP-ASI Dini, diperoleh nilai $\mathrm{x}^{2}=7,834$ dan nilai $p=0,020<\alpha=0,05 \mathrm{Ho}$ ditolak dan Ha diterima artinya terdapat hubungan yang bermakna antara pengetahuan ibu dengan pemberian MPASI Dini di Desa Boloh Kecamatan Toroh Kabupaten Grobogan. 


\section{Hubungan Pengalaman Ibu dengan Pemberian MP-ASI Dini}

\section{Tabel 13}

Hubungan Pengalaan dengan Pemberian MP-ASI Dini

Di Desa Boloh KecamatanToroh Kabupaten Grobogan Bulan Juni $2016 \quad(\mathrm{n}=78)$

\begin{tabular}{|c|c|c|c|c|c|c|c|c|}
\hline \multirow[t]{3}{*}{ Pengalaman } & \multicolumn{4}{|c|}{$\begin{array}{l}\text { Pemberian } \\
\text { MP-ASI Dini }\end{array}$} & \multirow{2}{*}{\multicolumn{2}{|c|}{ Total }} & \multirow[t]{2}{*}{$\mathbf{x}^{2}$} & \multirow[t]{2}{*}{$\begin{array}{c}\mathbf{p} \\
\text { value }\end{array}$} \\
\hline & \multicolumn{2}{|c|}{$\mathrm{Ya}$} & \multicolumn{2}{|c|}{ Tidak } & & & & \\
\hline & $\mathrm{n}$ & $\%$ & $\mathrm{n}$ & $\%$ & $\mathrm{n}$ & $\%$ & 7,834 & 0,020 \\
\hline Kurang & 16 & 20,5 & 1 & 1,3 & 17 & 21,8 & & \\
\hline Cukup & 14 & 17,9 & 12 & 15,4 & 26 & 33,3 & & \\
\hline Baik & 17 & 21,8 & 18 & 23,1 & 35 & 44,9 & & \\
\hline Jumlah & 47 & 60,3 & 31 & 39,7 & 78 & 100 & & \\
\hline
\end{tabular}

Hasil uji Chi-square untuk mengetahui hubungan antara pengalaman ibu dengan pemberian MP-ASI Dini, diperoleh nilai $\mathrm{x}^{2}=10,581$ dan nilai $p=0,005<\alpha=0,05$ Ho ditolak dan $\mathrm{Ha}$ diterima artinya terdapat hubungan yang bermakna antara pengalaman ibu dengan pemberian MP-ASI Dini di Desa Boloh Kecamatan Toroh Kabupaten Grobogan.

\section{Hubungan Sosial Budaya dengan Pemberian MP-ASI Dini}

Tabel 14

Hubungan Sosial Budayadengan Pemberian MP-ASI Dini

Di Desa Boloh KecamatanToroh Kabupaten Grobogan

Bulan Juni 2016 ( $\mathrm{n}-=78)$

\begin{tabular}{|c|c|c|c|c|c|c|c|c|}
\hline \multirow{3}{*}{$\begin{array}{c}\text { Sosial } \\
\text { Budaya }\end{array}$} & \multicolumn{4}{|c|}{ Pemberian MP-ASI Dini } & \multirow{2}{*}{\multicolumn{2}{|c|}{ Total }} & \multirow[t]{3}{*}{$\mathbf{x}^{2}$} & \multirow{3}{*}{$\begin{array}{l}\mathbf{p} \\
\text { value }\end{array}$} \\
\hline & \multicolumn{2}{|l|}{ Ya } & \multicolumn{2}{|c|}{ Tidak } & & & & \\
\hline & $\mathrm{n}$ & $\%$ & $\mathrm{n}$ & $\%$ & $\mathrm{n}$ & $\%$ & & \\
\hline Terpengaruh & 28 & 35,9 & 7 & 9,0 & 35 & 44,9 & 10,334 & 0,001 \\
\hline $\begin{array}{l}\text { Tidak } \\
\text { Terpengaruh }\end{array}$ & 19 & 24,4 & 24 & 30,8 & 43 & 55,1 & & \\
\hline Jumlah & 47 & 60,3 & 31 & 39,7 & 78 & 100 & & \\
\hline
\end{tabular}

Hasil uji statistik dengan menggunakan uji Chi-square untuk mengetahui hubungan antara sosial budaya dengan pemberian MP-ASI Dini di Desa Boloh Kecamatan Toroh Kabupaten Grobogan, diperoleh nilai $\mathrm{x}^{2}=10,334$ dan nilai $p=0,001<=0,05$, maka Ha diterima dan Ho ditolak artinya terdapat hubungan yang bermakna antara sosial budaya dengan pemberian MP-ASI Dini di Desa Boloh Kecamatan Toroh Kabupaten Grobogan. 


\section{Hubungan Informasi dengan Pemberian MP-ASI Dini}

Tabel 15

Hubungan Informasi dengan Pemberian MP-ASI Dini

Di Desa Boloh Kecamatan Toroh Kabupaten Grobogan

Bulan Juni $2016(\mathrm{n}=78)$

\begin{tabular}{|c|c|c|c|c|c|c|c|c|}
\hline \multirow[t]{3}{*}{$\begin{array}{c}\text { Informa } \\
\text { si }\end{array}$} & \multicolumn{4}{|c|}{$\begin{array}{l}\text { Pemberian MP-ASI } \\
\text { Dini }\end{array}$} & \multirow{2}{*}{\multicolumn{2}{|c|}{ Total }} & \multirow[t]{3}{*}{$\overline{x^{2}}$} & \multirow[t]{3}{*}{$\begin{array}{l}p \\
\text { value }\end{array}$} \\
\hline & \multicolumn{2}{|l|}{$\mathrm{Ya}$} & \multicolumn{2}{|c|}{ Tidak } & & & & \\
\hline & $\mathrm{n}$ & $\%$ & $\mathrm{n}$ & $\%$ & $\mathrm{n}$ & $\%$ & & \\
\hline $\begin{array}{l}\text { Tidak } \\
\text { Terpeng } \\
\text { aruh }\end{array}$ & 18 & 23,1 & 24 & 30,8 & 42 & 53,8 & 11,504 & 0,001 \\
\hline $\begin{array}{l}\text { Terpeng } \\
\text { aruh }\end{array}$ & 29 & 37,2 & 7 & 9,0 & 36 & 6,2 & & \\
\hline Jumlah & 47 & 60,3 & 31 & 39,7 & 78 & 100 & & \\
\hline
\end{tabular}

Hasil uji statistik dengan uji Chisquare untuk mengetahui hubungan antara informasi dengan pemberian MP-ASI Dini, diperoleh nilai $\mathrm{x}^{2}=11,504$ dan nilai $p=0,001<\alpha=0,05$ Ho ditolak dan Ha diterima artinya terdapat hubungan yang bermakna antara informasi dengan pemberian MP-ASI Dini di Desa Boloh Kecamatan Toroh Kabupaten Grobogan.

\section{PEMBAHASAN}

\section{Usia Ibu}

Usia dewasa awal merupakan usia seseorang untuk dapat memotivasi diri memperoleh pengetahuan sebanyakbanyaknya. Usia mempengaruhi daya tangkap dan pola pikir seseorang. Semakin cukup umur, tingkat kematangan seseorang akan lebih matang dalam berfikir dan bekerja. Dari segi kepercayaan masyarakat seseorang yang lebih dewasa akan lebih dipercaya dari pada orang yang belum cukup tinggi kedewasaannya (Notoadmodjo, 2007).

Umur merupakan periode terhadap pola-pola kehidupan baru dan harapanharapan baru. Semakin bertambahnya umur seseorang semakin banyak pula ilmu pengetahuan yang dimiliki (Notoadmodjo, 2007 ).

\section{Status Pekerjaan}

Status pekerjaan Ibu juga dapat mempengaruhi dalam pemberian MP-ASI dini. Ibu yang tidak bekerja lebih berisiko dalam pemberian MP-ASI dini. Hal ini disebabkan karena ibu-ibu hanya berdiam diri dirumah sehingga ibu-ibu tidak mendapatkan informasi mengenai kesehatan disusul masih kuatnya pengaruh sosial budaya yang masih kental dalam hal bayi yang cepat diberi makan akan gemuk, dan gemuk itu sehat ( Septiyani, 2014 ).

Masyarakat yang sibuk akan memiliki waktu yang sedikit untuk memperoleh informasi, sehingga tingkat pendidikan yang mereka peroleh juga berkurang, sehingga tidak ada waktu untuk memberikan ASI pada bayinya dan cenderung memberikan MP-ASI pada bayi (Markum, 2003).

\section{Pendidikan}

Menurut Priyoto ( 2014 ) pendidikan adalah proses perubahan sikap dan tata laku seseorang atau kelompok orang dalam usaha mendewasakan manusia melalui upaya pengajaran dan pelatihan. Melalui 
pendidikan kesehatan masyarakat diharapkan mampu memelihara kesehatan mereka, menghindari hal-hal yang merugikan kesehatan, dan mampu mencari upaya pengobatan apabila sakit (Sulistyoningsih, 2011 ).

\section{Pengetahuan}

Menurut Notoadmodjo (2007) Pengetahuan adalah merupakan hasil "tahu" setelah terjadi penginderaan terhadap objek terjadi melalui panca indra manusia yakni penglihatan, pendengaran, penciuman, rasa dan raba dengan sendiri.

\section{Pengalaman}

Menurut Notoadmodjo (2005) Pengalaman pribadi seseorang dimasa lalu akan membawa seseorang memecahkan masalah pada masa yang akan datang. Ibu yang sudah mempunyai anak lebih dari satu cenderung memiliki pengalaman yang cukup dalam mengasuh anaknya terutama dalam pemberian MP-ASI Dini, kemungkinan ibu sebelumnya sudah pernah memberi MP-ASI Dini kepada bayinya sehingga ibu akan meneruskan pengalaman tersebut pada anak berikutnya.

dalam menerima informasi. Kebudayaan telah mewarnai sikap anggota. masyarakatnya, karena kebudayaanlah yang memberi corak pengalaman individuindividu masyarakat asuhnya.

\section{Informasi}

Menurut Athfin dalam Arif ( 2012 ) banyaknya iklan yang memasarkan susu formula, membuat ibu mau memberikannya kepada bayi dengan keyakinan sehat dan baik bagi bayinya. Iklan tidak hanya melalui televisi, tapi juga radio dan surat kabar, dan brosur-brosur.

\section{Sosial Budaya}

Menurut Wawan dan Dewi ( 2010 ), Sosial budaya adalah apa yang ada pada masyarakat dapat mempengaruhi dari sikap dalam menerima informasi. Kebudayaan telah mewarnai sikap anggota. masyarakatnya, karena kebudayaanlah yang memberi corak pengalaman individuindividu masyarakat asuhnya.

\section{KESIMPULAN}

Hasil statistikmenunjukkan ada tujuh variabel yang memiliki hubungan sidnifikan dengan pemberian MP-ASI Dini yaitu usia ibu dengan nilai $\mathrm{p}_{\text {value }} \leq 0,05$ $(\mathrm{p}=0,028)$, status pekerjaan nilai $\mathrm{p}_{\text {value }} \leq$ $0,05(\mathrm{p}=0,002)$, tingkat pendidikan Dini nilai $\mathrm{p}_{\text {value }} \leq 0,05(\mathrm{p}=0,001)$, pengetahuan nilai $p_{\text {value }} \leq 0,05 \quad(p=0,020)$, pengalaman nilai $\mathrm{p}_{\text {value }} \leq 0,05(\mathrm{p}=0,005)$, sosial budaya $\mathrm{p}_{\text {value }} \leq 0,05(\mathrm{p}=0,001)$, informasi nilai $\mathrm{p}_{\text {value }}$ $\leq 0,05(\mathrm{p}=0,001)$. Maka Ada hubungan yang signifikan antara umur ibu, status pekerjaan,tingkat pendidikan, pengetahuan, pengalaman, sosial budaya, dan informasi.

\section{DAFTAR PUSTAKA}

Arip, Setiawan. 2014. Hubungan Pemberian Makanan Tambahan Dini dengan Kejadian Diare pada Bayi Usia 0-6 bulan di Desa Kemuning Kabupaten Karanganyar Kota Solo

Artini, Budi. 2013. Gambaran Faktor faktor yang Mempengaruhi Pemberian MPASI Dini Di RW 1 Kelurahan Ngagel Kecamatan Wonokromo Surabaya

Daulat, Ginting. 2010. Pengaruh Karakteristik, Faktor Internal dan

Eksternal Ibu Terhadap Pemberian MPASI Dini pada Bayi Usia <6 Bulan di Wilayah Kerja Puskesmas Barusjahe Kabupaten Karo Provinsi Sumatera Utara 
Ellya, Eva Sibagariang. 2010. Gizi dalam Kesehatan Reproduksi. Jakarta : TIM

Eprints.UMS.ac.id/ 23651/ 12/ Naskah_publikasi. Pdf. Hubungan Tingkat Pengetahuan Ibu tentang Makanan Pendamping ASI. Diakses pada tanggal 19 Februari 2016 pukul 10.11 WIB

Lestari, Eka. 2012. Faktor - Faktor yang mempengaruhi Perilaku Ibu dalam Pemberian MPASI Dini di Desa Jungsemi Kecamatan kangkung Kabupaten Kendal

Notoadmodjo,Soekidjo. 2007. Prinsip prinsip Dasar Ilmu Kesehatan Masyarakat. Jakarta : Rineka Cipta

Notoadmodjo,Soekidjo. 2010. Metodologi Penelitian Kesehatan. Jakarta : Rineka Cipta

Notoadmodjo,Soekidjo. 2012. Promosi Kesehatan dan Perilaku Kesehatan ( Edisi Revisi 2012 ). Jakarta : Rineka Cipta

Priyoto. 2014. Teori Sikap Dan Perilaku Dalam Kesehatan. Yogyakarta : Nuha Medika

Saryono. 2013. Metodologi Penelitian Kualitatif dan Kuantitatif dalam Bidang Kesehatan. Yogyakarta : Nuha Medika

Simanjuntak. 2007. Gambaran Pengetahuan Ibu tentang Pola Pemberian ASI, MP-ASI dan Pola Penyakit pada Bayi Usia 0-12 bulan di Dusun III Desa Limau Manis Kecamatan Tanjung Morawa Kabupaten Deli Serdang.

Solicaturrohmah, D. 2012. Karakteristik ibu yang berhubungan dalam pemberian makanan pendamping asi pada bayi usia 0-6 bulan di desa Tambahrejo kecamatan Pageruyung kabupaten Kendal. Kendal : Stikes Kendal.

Sulistyoningsih, Haryani. 2011. Gizi untuk Kesehatan Ibu dan Anak, edisi I. Yogyakarta : Graha Ilmu

Wawan dan Dewi. 2010. Teori dan Pengukuran Pengetahuan Sikap dan Perilaku Manusia. Yogyakarta : Nuha Medika. 